J. Clin. Chem. Clin. Biochem.

Vol. 16, 1978, pp. 175-185

\title{
A Comparative Study of the Electrode Systems of Three pH and Blood Gas Apparatus
}

\author{
By E. K. A. Winckers, A. J. Teunissen, R. A. M. Van den Camp, A. H. J. Maas \\ Departments of Surgery, Cardiology and Cardiovascular Surgery, University Hospital, Utrecht
}

and

\section{A. H. Veefkind}

Department of Medical Physics, Free University, Amsterdam, the Netherlands

(Received February 10/August 26, 1977)

Summary: We present a comparative evaluation of the electrode systems of three modern blood gas analysers: IL-413, ABL-1 and AVL-937C.

The response curves, accuracy and precision of the $\mathrm{pH}-, \mathrm{pCO}_{2}$ - and $\mathrm{pO}_{2}$-electrodes were established with tonometered blood and buffer solutions.

$\mathrm{pH}$ values (range 6.8-7.8) measured on the AVL deviate $(-0.03 \mathrm{pH}$ for blood and $+0.03 \mathrm{pH}$ for buffer) from those of BMS2 Mk2; whereas on the $\mathrm{IL}$ and $\mathrm{ABL}$ analysers the $\mathrm{pH}$ values deviate by not more than $0.01 \mathrm{pH}$. The standard deviation was better than $0.005 \mathrm{pH}$.

$\mathrm{pCO}_{2}$ values of blood and buffer (range 14-106 $\mathrm{mm} \mathrm{Hg}$ ) deviate from the calculated tonometer values by quantities ranging from 3 to $10 \mathrm{~mm} \mathrm{Hg}$. The average precision $\left.(\overline{\mathrm{CV}})^{1}\right)$ of the $\mathrm{pCO}_{2}$ measurement on each analyser was better than $1.8 \%$.

$\mathrm{pO}_{2}$ values of blood (range 0-130 $\mathrm{mm} \mathrm{Hg}$ ) did not differ by more than $3 \mathrm{~mm} \mathrm{Hg}$ from the calculated values. Above $130 \mathrm{~mm} \mathrm{Hg}$ a linear negative increasing difference was seen.

For buffer solutions a linear relationship between $\mathrm{pO}_{2}$ difference and $\mathrm{pO}_{2}$ value was found over the whole range from zero up to $642 \mathrm{~mm} \mathrm{Hg}$ : a positive difference below and a negative difference above the $\mathrm{pO}_{2}$ of the previous calibration; if the calibration $\mathrm{pO}_{2}$ is higher, the sample $\mathrm{pO}_{2}$ is shifted to a higher value.

The average precision of the $\mathrm{pO}_{2}$ measurements was better than $3 \%$. In the (patho)-physiological range the three instruments may provide suitable results for the clinician. Suggestions are made for standardization and improvement of the electrode systems.

\section{Vergleichende Untersuchung der Elektrodensysteme von drei pH- und Blutgas-Meßgeräten}

Zusammenfassung: Eine vergleichende Bewertung der Elektrodensysteme von drei modernen Blutgasanalysatoren (Il-413, ABL̄-1, AVL-937C) wird vorgestellt.

Ansprechbarkeit, Richtigkeit und Zuverlässigkeit der $\mathrm{pH}$-, $\mathrm{pCO}_{2}$ - und $\mathrm{pO}_{2}$-Elektroden wurden mit tonometriertem Blut und Pufferlösungen festgestellt.

Die am AVL gemessenen pH-Werte (Bereich 6,8-7,8) weichen für Blut um - 0,03 und für Puffer um $+0,03$ von den mit dem BMS2 Mk2 gemessenen ab, während sie am IL und ABL nicht mehr als 0,01 pH abweichen. Die Standardabweichung war besser als $0,005 \mathrm{pH}$.

$\mathrm{pCO}_{2}$-Werte von Blut und Puffer (Bereich 14-106 mm Hg) weichen von den berechneten Tonometer-Werten um

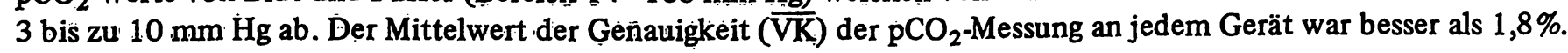

$\mathrm{pO}_{2}$-Werte von Blut (Bereich 0-130 mmHg) differierten um nicht mehr als $3 \mathrm{~mm} \mathrm{Hg}$ von den berechneten Werten. Oberhalb $130 \mathrm{~mm} \mathrm{Hg}$ wurde eine lineare, negativ steigende Differenz beobachtet.

1) $\overline{\mathrm{CV}}$ : average coefficient of variation. 
Für Pufferlösungen wurde eine lineare Beziehung $\mathrm{zwischen} \mathrm{pO}_{2}$-Differenz und $\mathrm{pO}_{2}$-Wert über den gesamten Bereich von 0 bis $642 \mathrm{~mm} \mathrm{Hg}$ gefunden: eine positive Differenz unterhalb und eine negative oberhalb des $\mathrm{pO}_{2}$ des letzten Kalibriergases; wenn das $\mathrm{pO}_{2}$ des Kalibriergases höher ist, weicht der $\mathrm{pO}_{2}$-Wert der Probe zu einem höheren Wert hin ab und umgekehrt.

Der Mittelwert der Genauigkeit ( $(\overline{\mathrm{VK}})$ für die $\mathrm{pO}_{2}$-Messungen war besser als $3 \%$. Im (patho)-physiologischen Bereich können die drei Instrumente dem Kliniker ausreichende Ergebnisse vermitteln. Vorschläge für die Standardisierung und Verbesserung der Elektrodensysteme werden gemacht.

\section{Introduction}

The importance of providing an accurate, precise and rapid blood gas analysis has been recognized by physicians in clinical disciplines, such as pulmonology, cardiology, thoracic surgery, intensive care, resuscitation and anaesthesiology. The $\mathrm{pH}, \mathrm{pCO}_{2}$ and $\mathrm{pO}_{2}$ determination of blood often gives essential information for the diagnosis and care of patients whose life is at risk.

Initially the measurements of $\mathrm{pH}, \mathrm{pCO}_{2}$ and $\mathrm{pO}_{2}$ were made separately and the whole procedure was laborious. The increase in the number of demands for blood gas analysis from the clinic has, however, stimulated several manufacturers to develop more sophisticated, fast and automatic blood gas systems, designed for simultaneous measurement of $\mathrm{pH}, \mathrm{pCO}_{2}$ and $\mathrm{pO}_{2}$.

Sources of error associated with $\mathrm{pH}$ and blood gas measurement are well described (1-8) and reviewed (9-11). If the sources of error are not carefully under control, the risk of an analytical bias is great as demonstrated by Miller \& Tutt (12) who compared blood gas instruments of four manufacturers. Hill \& Tilsley (13) found systematic deviations from the stated values using tonometered blood samples. Similar observations were made by others (14-16).

We were stimulated by these facts to compare and evaluate the operation of the electrode systems of three modern blood gas analysers, namely the IL (Instrumentation Laboratories Inc., Lexington, Mass., U.S.A.) Model-413, the ABL Radiometer, Copenhagen, Denmark) Model-1, and the AVL (AVL AG, Schaffhausen, Switzerland) Model-937C. The response, accuracy and precision of the electrode systems were tested with both tonometered blood (17) and buffer solution $\mathrm{AIII}^{2}$ ) (18). The latter may be applied for quality control (19). For reference pH measurements, the BMS2 (Radiometer, Copenhagen, Denmark) Model Mk2 was used.

\section{Materials and Methods}

\section{Apparatus}

Table 1 shows important features and specifications of the different instruments as given by the manufacturers.

\footnotetext{
2) See material and methods.
}

\section{Design}

The cells for $\mathrm{pH}$ measurement consist of a glass electrode and a reference electrode which is connected with the sample by an open salt bridge in the $A B \dot{L}$ and by a salt bridge with a permeable membrane in the IL and AVL; the $\mathrm{KCl}$ concentration in the bridges is different.

The principle of the $\mathrm{pCO}_{2}$ electrode is based on $\mathrm{pH}$ measurement in a bicarbonate layer which is embedded in a nylon matrix in $A B L$ and IL, and in a piece of cellophane in the AVL. The layer is separated from the sample by a teflon membrane in the ABL and AVL and by an Ilastic membrane, which is more permeable to carbon dioxide, in the IL. The electrode sensitivity ( $\mathrm{S}=$ $-\mathrm{dpH} / \mathrm{dlog} \mathrm{pCO}_{2}$ ) of IL and ABL is approximately 0.95 , and of AVL below 0.90 as a result of the buffering effect of the cellophane.

The $\mathrm{pO}_{2}$ electrode is a polagraphic cell consisting of a platinum cathode and a silver/silver chloride anode, immersed in an electrolyte solution and covered with a membrane of propylene in the IL and ABL and of teflon in the AVL. The cathode of the AVL electrode consists of more threads of platinum.

\section{Procedure}

The operations of calibration, sampling, reading and rinsing are different on the three instruments and are described in more detail below.

\section{IL-413}

A complete calibration for $\mathrm{pH}, \mathrm{pCO}_{2}$ and $\mathrm{pO}_{2}$ electrodes can be done by alternate selection of two push buttons: cal 1 and cal 2 .

Calibration 1 is done with phosphate buffer $\mathrm{pH}=7.384$ and.a gas mixture (low gas) composed of carbon dioxide and air.

Calibration 2 is done with a phosphate buffer $\mathrm{pH}=6.840$ and a gas mixture (high gas) composed of carbon dioxide and nitrogen (tab. 1).

In our set-up the gas-mixtures for calibration were delivered by a pair of gas mixing pumps (type A27/2F. Wösthoff. Bochum, Germany).

Before sampling the $\mathrm{pH}$ electrode and the gas electrodes are exposed to the conditions of cal 1.

Two push buttons are used for sampling. By pressing the "tip" button the sample path is cleared and the sampling tip presented. By pressing the "sample" button the aspiration of the sample is initiated. This operation can be performed automatically or manually.

Separate "ready" indications light up according to the preset limits (see tab. 1) for each electrode. When all three electrode signals indicate "ready", a "data" indication light appears. The instrument memory stores the values for $\mathrm{pH}, \mathrm{pCO}_{2}$ and $\mathrm{pO}_{2}$ at time "data" for computation.

The working cycle is finished with a rinsing and a calibration step (cal 1). Rinsing of the sample path is performed in a direction opposite to sampling, to prevent obstruction of the sample path by blood-clots.

ABL-1

Calibration, sampling, reading and rinsing are fully automated and controlled by a computer. Every two hours the three electrodes are calibrated with two gas equilibrated phosphate buffer solutions (tab. 1). Calibration of $\mathrm{pO}_{2}=0 \mathrm{~mm} \mathrm{Hg}$ is performed electrically. 
Tab. 1. Specifications of the $\mathrm{pH}, \mathrm{pCO}_{2}$ and $\mathrm{pO}_{2}$ clectrode systems.

\begin{tabular}{|c|c|c|c|c|}
\hline & & IL-413 & ABL-1 & AVL-937C \\
\hline $\mathrm{pH}$ & $\begin{array}{l}\text { glass clectrode } \\
\text { liquid junction }\end{array}$ & $\begin{array}{l}\text { capillary type } \\
\text { cellophanc } \\
4.3 \mathrm{~mol} / 1 \mathrm{KCl}\end{array}$ & $\begin{array}{l}\text { flat membrane } \\
\text { open } \\
3.0 \mathrm{~mol} / 1 \mathrm{KCl}\end{array}$ & $\begin{array}{l}\text { flat membrane } \\
\text { cellulose acetate } \\
1.0 \mathrm{~mol} / 1 \mathrm{KCl}\end{array}$ \\
\hline $\mathrm{PCO}_{2}$ & $\begin{array}{l}\text { membrane } \\
\text { thickness } \\
\text { spacer } \\
\text { eloctrolyte }\end{array}$ & $\begin{array}{l}\text { ILastic } \\
100 \mu \mathrm{m} \\
\text { nylon } \\
100 \mathrm{mmol} / 1 \mathrm{NaCl} \\
20 \mathrm{mmol} / 1 \mathrm{NaHCO}\end{array}$ & $\begin{array}{l}\text { teflon } \\
12 \mu \mathrm{m} \\
\text { nylon } \\
20 \mathrm{mmol} / 1 \mathrm{NaCl} \\
5 \mathrm{mmol} / 1 \mathrm{NaH} \mathrm{CO}_{3}\end{array}$ & $\begin{array}{l}\text { teflon } \\
15 \mu \mathrm{m} \\
\text { ccllophane } \\
25 \mathrm{mmol} / 1 \mathrm{KCl} \\
1 \mathrm{mmol} / 1 \mathrm{NaHCO} 3\end{array}$ \\
\hline $\mathrm{pO}_{2}$ & $\begin{array}{l}\text { membrane } \\
\text { thickncss } \\
\text { cathode, diametor } \\
\text { polarizing voltage } \\
\text { electrolyte }\end{array}$ & $\begin{array}{l}\text { polypropylene? } \\
25 \mu \mathrm{m} \\
700 \mathrm{mV} \\
10 \mathrm{mmol} / 1 \mathrm{KH}_{2} \mathrm{PO}_{4} \\
10 \mathrm{mmol} / 1 \mathrm{~K}_{2} \mathrm{HPO}_{4} \\
100 \mathrm{mmol} / 1 \mathrm{KCl}\end{array}$ & $\begin{array}{l}\text { polypropylene } \\
20 \mu \mathrm{m} \\
20-25 \mu \mathrm{m} \\
630 \mathrm{mV} \\
470 \mathrm{mmol} / 1 \text { phosphatc buffer } \\
\mathrm{pH} 7 \\
134 \mathrm{mmol} / 1 \mathrm{KCl} \text { saturated } \\
\text { with } \mathrm{Ag} \mathrm{Cl}\end{array}$ & $\begin{array}{l}\text { teflon } \\
25 \mu \mathrm{m} \\
50 \mu \mathrm{m}(4 \text { threads of } 12.5 \mu \mathrm{m}) \\
700 \mathrm{mV} \\
153 \mathrm{mmol} / 1 \mathrm{NaCl}\end{array}$ \\
\hline \multirow[t]{5}{*}{ General } & gas mixing device & external & internal & internal \\
\hline & $\begin{array}{l}\text { Calibration } \\
(B=760 \mathrm{~mm} \mathrm{Hg})\end{array}$ & $\begin{array}{l}\mathrm{Cal} 1 \\
\mathrm{pH} 7.384 \\
(1: 3.5 \mathrm{NBS} \text { *) phosphate, IL) } \\
\mathrm{pCO}_{2} 35 \mathrm{~mm} \mathrm{Hg} \\
\mathrm{pO}_{2} 140 \mathrm{~mm} \mathrm{Hg} \\
\mathrm{Cal} 2 \\
\mathrm{pH} 6.840 \\
(1: 1 \mathrm{NBS} \text { phosphate, IL) } \\
\mathrm{pCO}_{2} 70 \mathrm{~mm} \mathrm{Hg} \\
\mathrm{pO}_{2} 0 \mathrm{~mm} \mathrm{Hg}\end{array}$ & $\begin{array}{l}\text { "green" calibrating solution } \\
\mathrm{pH} 6.841 \\
\mathrm{pCO}_{2} 82 \mathrm{~mm} \mathrm{Hg} \\
\mathrm{pO}_{2} 132 \mathrm{~mm} \mathrm{Hg} \\
\text { "red" callbrating solution } \\
\mathrm{pH} 7.383 \\
\mathrm{pCO}_{2} 41 \mathrm{~mm} \mathrm{Hg} \\
\mathrm{pO}_{2} \text { not measured }\end{array}$ & 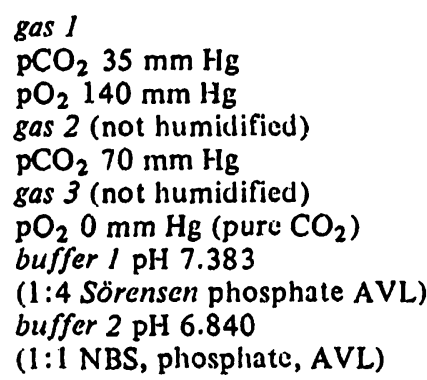 \\
\hline & $\begin{array}{l}\text { measuring mode } \\
\text { sample volume } \\
\text { rinsing solution }\end{array}$ & $\begin{array}{l}\text { manual and automatic } \\
350 \mu \mathrm{l} ; 100 \mu \mathrm{l} \text { (micro) } \\
11 \mathrm{mmol} / 1 \mathrm{NaCl} \text { and } 8 \mathrm{mmol} / 1 \\
\mathrm{NaHCO}_{3} \text { bubbled with low gas }\end{array}$ & $\begin{array}{l}\text { automatic } \\
<500 \mu l \\
\text { salinc }\end{array}$ & $\begin{array}{l}\text { manual } \\
40-60 \mu \mathrm{l} \\
\text { distilled water }\end{array}$ \\
\hline & $\begin{array}{l}\text { clectrode preset } \\
\text { limits }\end{array}$ & $\begin{array}{l}\mathrm{pH}<0.02 \mathrm{pH} / \mathrm{min} \\
\mathrm{pCO}_{2}<2.0 \mathrm{~mm} \mathrm{Hg} / \mathrm{min} \\
\mathrm{pO}_{2}<2.0 \mathrm{~mm} \mathrm{Hg} / \mathrm{min}\end{array}$ & print-out after $120 \mathrm{~s}$ & $\begin{array}{l}\mathrm{pH}<0.012 \mathrm{pH} / \mathrm{min} \\
\mathrm{pCO}_{2}<1.2 \mathrm{~mm} \mathrm{Hg} / \mathrm{min} \\
\mathrm{pO}_{2}<1.2 \mathrm{~mm} \mathrm{Hg} / \mathrm{min}\end{array}$ \\
\hline & $\begin{array}{l}\text { electrode "ready" } \\
\text { indications } \\
\text { simultancously } \\
\text { visible } \\
\text { read outs }\end{array}$ & $\begin{array}{l}\text { one for each clectrode } \\
\text { one }\end{array}$ & $\begin{array}{l}\text { none } \\
\text { three }\end{array}$ & $\begin{array}{l}\text { only onc for three electrodes } \\
\text { one }\end{array}$ \\
\hline
\end{tabular}

*) NBS: National Bureau of Standards

Values for $\mathrm{pH}, \mathrm{pCO}_{2}$ and $\mathrm{pO}_{2}$ are printed after a fixed period of $120 \mathrm{~s}$. Subsequently the rinsing cycle is initiated in the opposite direction. When the instrument is in "ready" position the cuvette is filled with humidified calibration gas 1 , which is replenished at $10 \mathrm{~min}$ intervals.

\section{AVL-937C.}

The instrument is cquipped with a commutator (sliding selector) with six opcrational positions: G1, G2, G3, M, W and S. The calibration of the pH clectrode and the gas electrodes is performed separately. Gas calibration is done using successively gas 1 (low $\mathrm{pCO}_{2}$ in air), gas 2 (high $\mathrm{pCO}_{2}$ in air) and gas 3 (pure carbon dioxide). Only gas 1 is humidified and thermostated (tab. 1). pH calibration has to be done by filling the capillary measuring chamber in the position $\mathrm{M}$, with the two phosphate buffers successively. The sample is introduced in the same position.
One "ready" indication light is used in succession for the three measuring channels. We decided however to read the $\mathrm{pO}_{2}$ value after $30 \mathrm{~s}$ and the $\mathrm{pCO}_{2}$ and $\mathrm{pH}$ after 2 min because the adjustment of the preset limits was not adequate as shown by the response curves of the electrodes (see results). Calibration adjustments were done at the same points of time.

When the commutator is in the position "wash-dry" the chamber is washed by intermittent suction of distilled water and air and dried by suction of air for twenty seconds.

\section{Gases}

Gases of known $\mathrm{pCO}_{2}$ and $\mathrm{pO}_{2}$ for tonometry were obtained by means of gas mixing pumps (typc $M-200$, mixing range $1-99 \%$, type $A 27 / 2 F$, mixing range $1-10 \%$ and $A 18 / 2 F$, mixing range of $10-90 \%$; Wösthoff, Bochum, Germany). The desired mixtures were made from pure carbon dioxide, nitrogen, oxygen and 
air, dried before use and mixed at the same pressure. The percentages of carbon dioxide and oxygen in the mixtures were verified by means of gas analysis with the Haldane-Lloyd apparatus (Gallenkamp, London). The relative accuracy of these gas mixtures was better than $1 \%$.

\section{Samples}

\section{Blood}

Fresh venous blood, drawn from volunteers or patients into heparinized collecting tubes, was used. To obtain blood samples with extremely low or high $\mathrm{pH}$ values isotonic solutions of $\mathrm{NaCl}$ with appropriate quantities of $\mathrm{NaHCO}_{3}$ or $\mathrm{HCl}$ were added (20).

\section{Buffer AIII}

Solutions were prepared, based on the composition of the NBS equimolal phosphate buffer, and $30 \mathrm{mmol} \mathrm{NaHCO}_{3}$ and 30 $\mathrm{mmol} \mathrm{NaCl}$ per liter were added (18).

\section{Tonometry}

Aliquots of 3 to $4 \mathrm{ml}$ blood or buffer AIII were equilibrated in a Laué tonometer (Eschweiler and Co., Kiel, Germany) with a pre-humidified gas mixture for at least 30 minutes. Both tonometer and humidifier were submerged in a water bath, maintained at $37^{\circ} \mathrm{C}$; fifteen different gas mixtures were employed; six containing carbon dioxide $(2-15 \%)$ in air and nine containing oxygen $(0-90 \%)$, carbon dioxide $(10 \%)$ and nitrogen to $100 \%$ by volume.

\section{Procedure}

Tonometered samples were carefully drawn from the tonometer with a $1 \mathrm{ml}$ disposable polystyrene syringe, flushed previously with tonometer gas. The samples were measured immediately according to the manufacturer's instructions with the exception of the above mentioned modifications of the reading time for AVL. Only one parameter $\left(\mathrm{pH}, \mathrm{pCO}_{2}\right.$ or $\left.\mathrm{pO}_{2}\right)$ was evaluated simultaneously on the three instruments.

The procedure for estimation of electrode response curves was as follows:

$I L-413$. After introduction of a tonometered sample in the "automatic" mode this knob was switched to "manual" and a stopwatch was started immediately.

During three minutes the electrode signal was read every $15 \mathrm{~s}$ from the digital screen.

$A B L-1$. During a measuring period of $120 \mathrm{~s}$ the first up-dating for each parameter appeared after $30 \mathrm{~s}$ and the subsequent updatings at $18 \mathrm{~s}$ intervals.

$A V L-937 C$. Immediately after sampling, a stopwatch was started and the electrode signals registered every $15 \mathrm{~s}$ for three minutes.

The reference $\mathrm{pH}$ determinations were performed on the BMS2, calibrated with precision phosphate buffers (type $S 1500$, $\mathrm{pH}=6.841$ and type S1510, $\mathrm{pH}=7.383$; Radiometer). Samples were aspirated in the electrode capillary three times without intermittent flushing and drying. For a comparison with the $\mathrm{pH}$ value obtained from the other instruments, the mean $\mathrm{pH}$ of the second and the third reading was used.

\section{Calculation}

The partial gas pressure of carbon dioxide or oxygen in a gas mixture of known composition was expressed in $\mathrm{mm} \mathrm{Hg}$, and calculated by multiplying the barometric pressure (B) minus the pressure of water vapor $\left(47 \mathrm{~mm} \mathrm{Hg}\right.$ at $\left.37^{\circ} \mathrm{C}\right)$, by the volume fraction of the respective gas.

Conversion of $\mathrm{pCO}_{2}$ and $\mathrm{pO}_{2}$ values into values at $760 \mathrm{~mm} \mathrm{Hg}$ is done by multiplying measured or calculated values by the factor (760-47)/(B-47).

The $p \mathrm{H}-\log \mathrm{pCO}_{2}$ relationship of buffer solution AIII was computed according to Veefkind et al (18).

\section{Results}

$\mathrm{pH}$

\section{Response curves}

Figure 1 shows the response curves of the $\mathrm{pH}$ electrodes for tonometered blood and buffer samples in the $\mathrm{pH}$ range 6.9-7.6.

The $\mathrm{pH}$ values between time "ready" and "data" for IL, and between the first updating and "print-out" for ABL do not differ by more than 0.005 of a $\mathrm{pH}$ unit, because drift is less than 0.002 of a $\mathrm{pH}$ unit/min within $30 \mathrm{~s}$.

On the AVL we found a drift of $0.010-0.015$ of a $\mathrm{pH}$ unit/min during $3 \mathrm{~min}$, although the green light usually indicated $\mathrm{pH}$ "ready" within $30 \mathrm{~s}$. Further investigations revealed a large drift at low $\mathrm{pH}$ coupled with high $\mathrm{pCO}_{2}$, and at high $\mathrm{pH}$ coupled with both low and high $\mathrm{pCO}_{2}$. This indicates that drift is caused on the one hand by leakage of carbon dioxide at the electrode edges, and on the other hand by a slow response of the electrode at more alkaline $\mathrm{pH}$. We have chosen a reading time at $120 \mathrm{~s}$ for the AVL, because at that time the drift is smaller in the higher $\mathrm{pH}$ range, and the calibration buffer has reached a plateau value.

\section{Accuracy}

The accuracy of the $\mathrm{pH}$ determination was established by comparing $\mathrm{pH}$ values from $\mathrm{IL}, \mathrm{ABL}$ or $\mathrm{AVL}$ with those from the BMS2 for blood (fig. 2) and buffer (fig. 3).

The estimated $\mathrm{pH}$ differences scattered within 0.015 of a pH unit for blood samples at each $\mathrm{pH}$ level for all three instruments, which was probably the result of the diversity of the blood samples. The figures illustrate a good agreement for IL and $\mathrm{ABL}$ up to $\mathrm{pH} 7.5 ; \mathrm{pH}$ values are comparable with $\mathrm{BMS} 2$ values within 0.01 of a $\mathrm{pH}$ unit. Above $\mathrm{pH} 7.5$ the $\mathrm{pH}$ differences of the IL values deviate while those of $\mathrm{ABL}$ remain constant.

The different behaviour of the electrodes could be explained by the different glasses used for their construction. As previously demonstrated (3) the efficiency factor of a glass electrode determined with two phosphate buffers over the $\mathrm{pH}$ range 6.8-7.4 might be too high for the range $\mathrm{pH}>7.4$. This effect is dependent on the kind of glass. The results with the ABL and BMS2 $\mathrm{pH}$ electrodes, which are manufactured from the same kind of glass, deviate from those obtained with the IL electrode, which is constructed from Ingold glass.

$\mathrm{pH}$ values for blood and buffer samples measured on the AVL deviate by about 0.03 of a pH unit from the BMS2 $\mathrm{pH}$ values. The opposite direction of these deviations: positive for buffer and negative for blood, is most peculiar. The large deviation for buffer could be explained partly by a pH difference of -0.015 of a pH unit of the calibration buffer " 7.383 "; ; we found a pH of 7.368 instead of 7.383 for three different batches of AVL phosphate buffer measured on the BMS2. The 

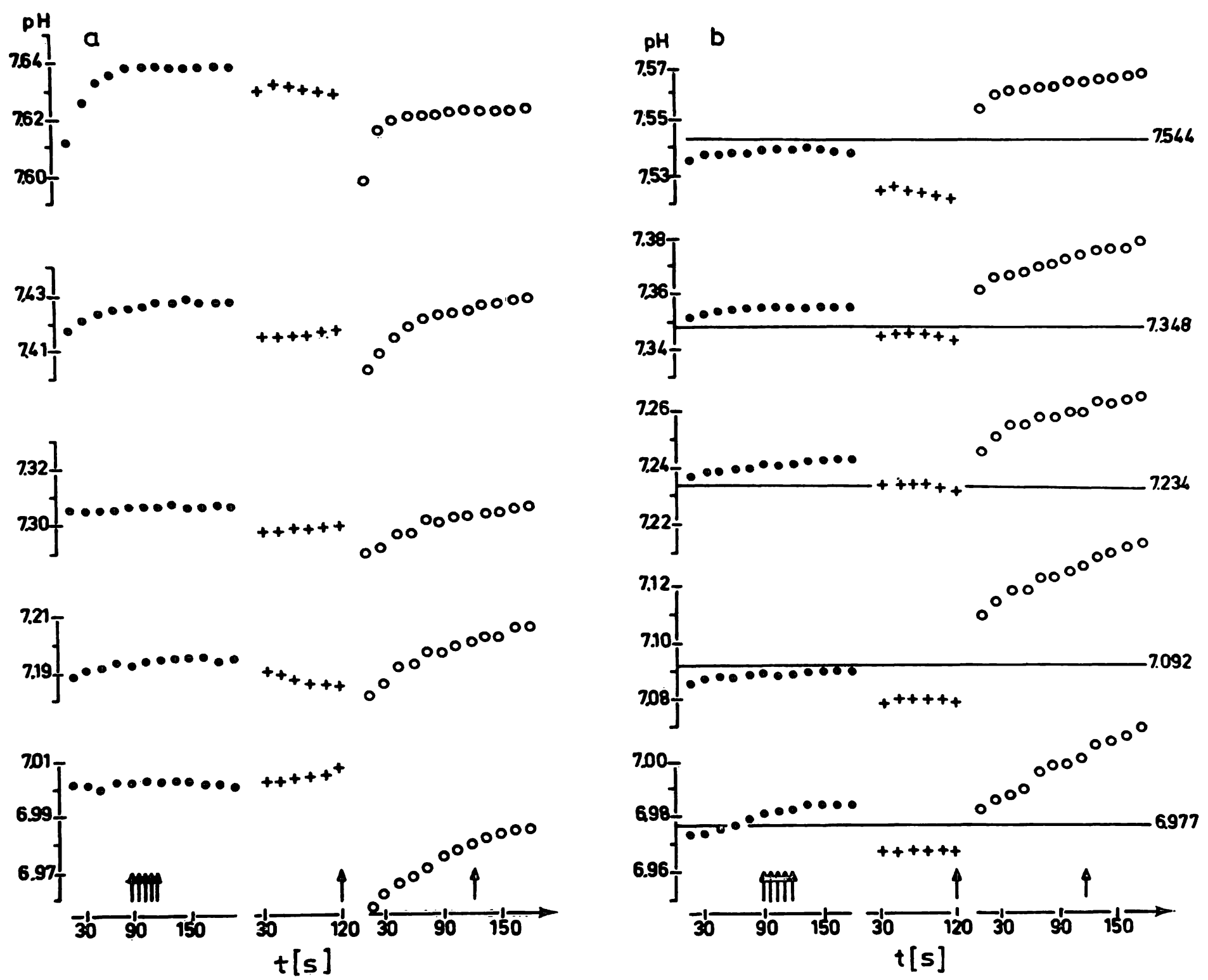

Fig. 1. pH response curves of blood (a) and buffer AIII (b). Each symbol is the mean of a duplicate. Arrows indicate at which time pH values of tonometered samples were read for the rest of this study. The horizontal lines in the graph of buffer AIII indicate calculated $\mathrm{pH}$ values (18).

$\bullet=I L-413+=$ ABL-1 $0=$ AVL-937C

remaining $0.015 \mathrm{pH}$ unit could have been caused by the above mentioned leakage of carbon dioxide. The negative deviation obtained with blood samples agrees with Voigt's (16) results for human control sera (Versatol, Acid-Base; General Diagnostics). Generally it is quite possible that systematically lower $\mathrm{pH}$ values are a result of filling the electrode system with sample only once (21). The $\mathrm{pH}$ readings from the second and third filling on the BMS2 electrode were in good agreement and were both higher than the $\mathrm{pH}$ reading after the first filling especially at higher $\mathrm{pH}$ valuẹes, as illustrated in figure 4 .

\section{Precision}

The standard deviations of the $\mathrm{pH}$ values of buffer solution at six $\mathrm{pH}$ levels $(\mathrm{n}=5)$ was less than 0.005 of a $\mathrm{pH}$ unit. The same result was found for the standard deviation of the $\mathrm{pH}$ duplicates of 52 blood samples (tab. 2).

$\mathrm{pCO}_{2}$

\section{Response curves}

The response curves of the $\mathrm{pCO}_{2}$ electrodes for blood and buffer samples are shown in figure 5. The shape of the curves is similar for both media and characteristic for each instrument: decreasing when the $\mathrm{pCO}_{2}$ is lower and increasing when $\mathrm{pCO}_{2}$ is higher than the $\mathrm{pCO}_{2}$ value of the calibration gas. On the IL the best approximation to the calculated values is achieved at "ready" time.

This signal coincides with the "data" signal because the $\mathrm{pCO}_{2}$ electrode has the slowest response in comparison with the $\mathrm{pH}$ and the $\mathrm{pO}_{2}$ electrodes. The printed $\mathrm{pCO}_{2}$ 


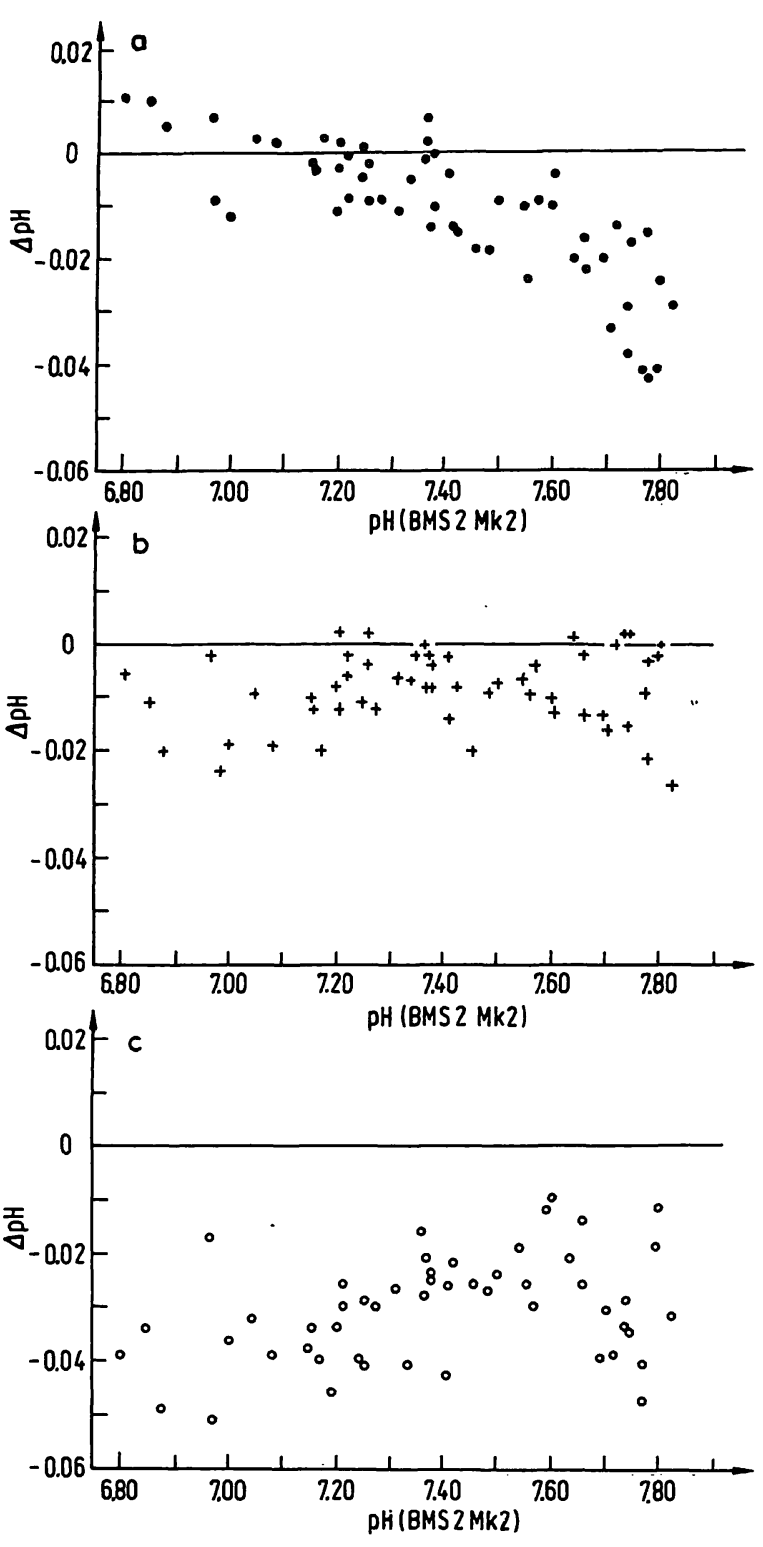

Fig. 2. Results of $\mathrm{pH}$ measurements for blood. The $\mathrm{pH}$ values measured on IL (a), ABL (b) and AVL (c) minus the $\mathrm{pH}$ measured on the BMS 2 are plotted on the $y$-axis.

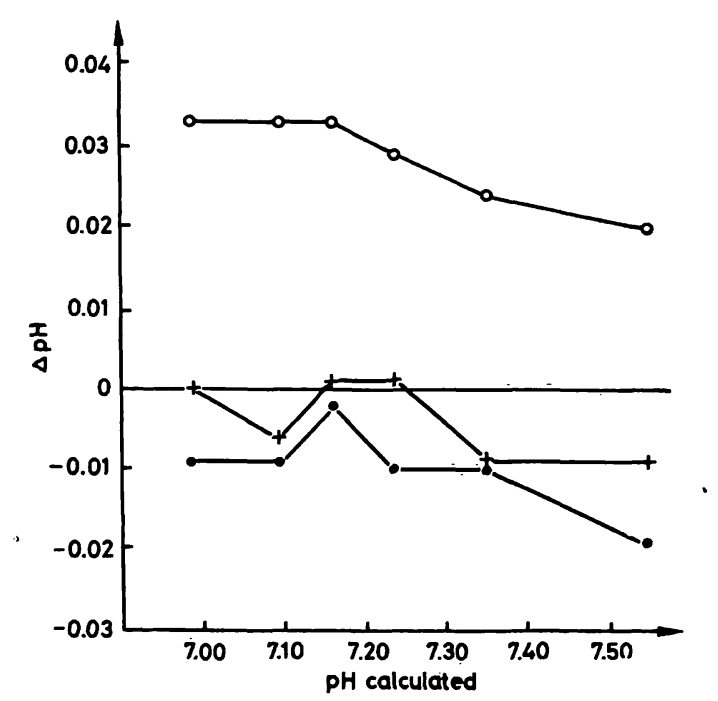

Fig. 3. Results of $\mathrm{pH}$ measurements for buffer AIII. The calculated $\mathrm{pH}$ is plotted on the $\mathrm{x}$-axis and the difference between measured and calculated $\mathrm{pH}$ on the $y=a x i s$. $\bullet=\mathrm{IL}-413+=\mathrm{ABL}-1 \quad 0=\mathrm{AVL}-937 \mathrm{C}$

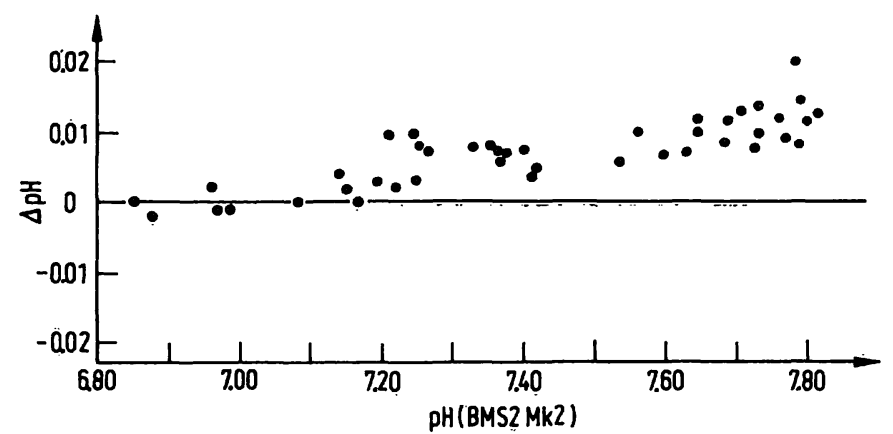

Fig. 4. The mean of the second and third $\mathrm{pH}$ reading minus the first $\mathrm{pH}$ reading as a function of $\mathrm{pH}$ level for blood with the micro glass electrode of BMS 2-Mk2.

Tab. 2. Precision of $\mathrm{pH}, \mathrm{pCO}_{2}$ and $\mathrm{pO}_{2}$ measurements

\begin{tabular}{lllll}
\hline Sample & Instrument & $\begin{array}{l}\mathrm{pH} \\
\left.\text { S.D. }{ }^{1}\right)\end{array}$ & $\begin{array}{l}\frac{\mathrm{pCO}_{2}}{\left.\overline{\mathrm{CV}}^{2}\right)} \\
{[\%]}\end{array}$ & $\begin{array}{l}\frac{\mathrm{pO}_{2}}{\left.\mathrm{CV}^{3}\right)} \\
{[\%]}\end{array}$ \\
\hline \multirow{3}{*}{ Blood } & IL & $<0.005$ & 0.7 & 1.4 \\
& $\mathrm{ABL}$ & $<0.005$ & 0.7 & 1.4 \\
& $\mathrm{AVL}$ & $<0.005$ & 1.8 & 1.7 \\
& $\mathrm{IL}$ & $<0.005$ & 0.5 & 2.8 \\
AIII & $\mathrm{ABL}$ & $<0.005$ & 1.5 & 2.5 \\
& $\mathrm{AVL}$ & $<0.005$ & 1.2 & 3.0 \\
\hline
\end{tabular}

1) S.D. was calculated from a $\mathbf{H}+$ values. 52 duplicate values were used for blood, and mean values at six pH levvels for 5 measurements were used for buffer AIII

2) The mean reproducibility $(\overline{\mathrm{CV}})$ was established by averaging the coefficient of variation $(\mathrm{CV})$ of six $\mathrm{pCO}_{2}$ levels from 14-106 mm Hg (blood $n=30$, buffer AIII $n=5$ at each level).

${ }^{3}$ ) The mean reproducibility ( $\left.\overline{\mathrm{CV}}\right)$ was established by averaging the coefficient of variation (CV) of eight $\mathrm{pO}_{2}$ levels from $0-642 \mathrm{~mm} \mathrm{Hg}$ (blood $\mathrm{n}=30$, buffer AIII $\mathrm{n}=5$ at each level).

values of the $\mathrm{ABL}$ are the best approximation to the calculated values. The readings on the AVL over the whole $\mathrm{pCO}_{2}$ range were performed at $120 \mathrm{~s}$, because for both high and low $\mathrm{pCO}_{2}$ values a plateau value was reached within $120 \mathrm{~s}$, in correspondence with the "ready" indication.

We may generally conclude that the optimum reading time of the $\mathrm{pCO}_{2}$ values agrees with the specifications of the manufacturers.

\section{Accuracy}

Table 3 presents the parameters for the linear regression analysis between calculated and measured $\mathrm{pCO}_{2}$ values for the range up to about $100 \mathrm{~mm} \mathrm{Hg}$, which demonstrate a good correlation $(r=0.99)$ but a positive $y$-intercept. The accuracy of the $\mathrm{pCO}_{2}$ measurement on different $\mathrm{pCO}_{2}$ levels is illustrated in figure 6. The deviation of the measured $\mathrm{pCO}_{2}$ from the calculated value is influenced by the $\mathrm{pCO}_{2}$ of the last calibration gas.(about 

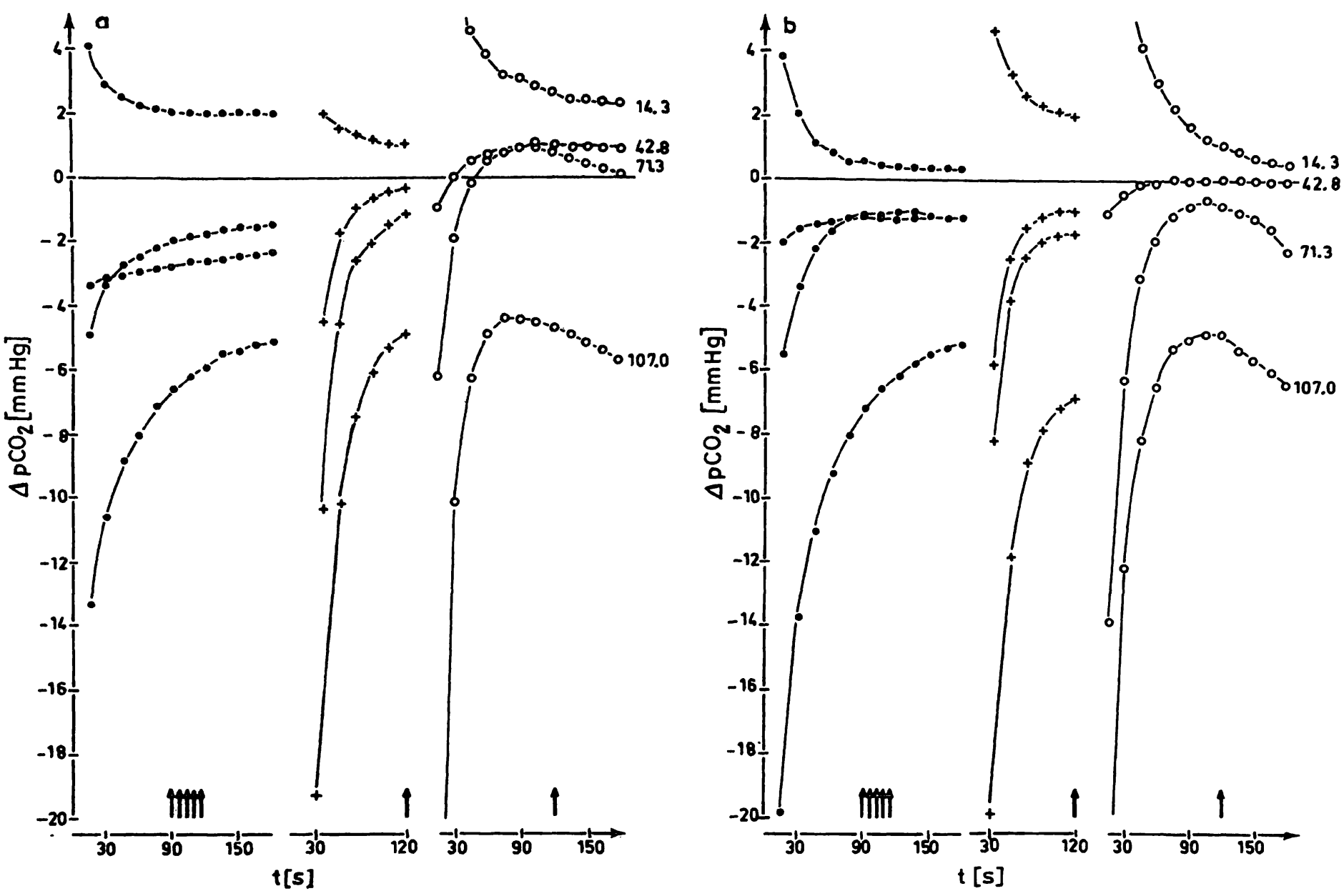

Fig. 5. $\mathrm{pCO}_{2}$ response curves of blood (a) and buffer $\mathrm{AIII}$ (b). The difference between measured and calculated $\mathrm{pCO}_{2}$ is plotted on the $y$-axis. Each symbol is the mean of a duplicate. The figures on the right side of the curves indicate the calculated tonometer $\mathrm{pCO}_{2}$ values. Arrows indicate at which time $\mathrm{pCO}_{2}$ values of tonometered samples were read.

$\bullet=\mathrm{IL}-413+=$ ABL-1 $0=$ AVL-937C

Tab. 3. Parameters of linear regressions of calculated $(x)$ and measured (y) $\mathrm{pCO}_{2}$ and $\mathrm{pO}_{2}$

\begin{tabular}{llllllll}
\hline & Sample & Instrument & Slope & y-Intercept & r & n \\
\hline & & IL & 0.87 & 4.08 & 0.998 & 18 \\
& Blood & ABL & 0.91 & 1.95 & 0.999 & 18 \\
& & AVL & 0.93 & 3.18 & 0.998 & 18 \\
$\mathrm{pCO}_{2}$ & & & & & & & \\
$14-106$ & & & & & & & \\
$\mathrm{~mm} \mathrm{Hg}$ & & IL & 0.85 & 6.18 & 0.996 & 6 \\
& AIII & ABL & 0.88 & 4.59 & 0.996 & 6 \\
& & AVL & 0.93 & 2.06 & 0.999 & 6 \\
& & & & 0.97 & 1.23 & 0.998 & 18 \\
& \multirow{3}{*}{ Blood } & IL & ABL & 0.98 & 2.24 & 0.998 & 18 \\
& & AVL & 1.04 & 0.40 & 0.999 & 18 \\
$\mathrm{pO}_{2}$ & & & & & & \\
$0-130$ & & & & & & & \\
$\mathrm{~mm} \mathrm{Hg}$ & & IL & 0.71 & 42.12 & 0.999 & 6 \\
& AllI & ABL & 0.81 & 29.28 & 0.999 & 6 \\
& & AVL & 0.76 & 36.66 & 0.998 & 6 \\
\hline
\end{tabular}

$35 \mathrm{~mm} \mathrm{Hg}$ ) before sampling. This "memory effect", caused by mixing of sample with gas still present in the measuring chamber and the electrode, has already been described by Berkenbosch (6) and Crampton-Smith
$(7,8)$. Because this effect is nearly the same for all instruments, a correction can be made for it.

\section{Precision}

Table 2 shows the average precision $(\overline{\mathrm{CV}})$ of the $\mathrm{pCO}_{2}$ at different levels. The coefficient of variation (CV) was better than 2 percent for blood and buffer samples.

$\mathrm{pO}_{2}$

\section{Response curves}

The response curves of the $\mathrm{pO}_{2}$ electrodes for blood and buffer samples are shown in figure 7. The curves from samples with $\mathrm{pO}_{2} \leqslant 128 \mathrm{~mm} \mathrm{Hg}$ reach a plateau after about $30 \mathrm{~s}$, and those with $\mathrm{pO}_{2} \geqslant 257 \mathrm{~mm} \mathrm{Hg}$ reach a distinct maximum.

For IL, $\mathrm{pO}_{2}$ values at time "ready" and "data" are broadly equal at $\mathrm{pO}_{2}$ levels up to $257 \mathrm{~mm} \mathrm{Hg}$. Above this gas terision a better approximation to the calculated $\mathrm{pO}_{2}$ is obtained if the "ready" value is used.

For $\mathrm{ABL}$, the $\mathrm{pO}_{2}$ values at print-out time are close to the calculated values. For AVL, the $\mathrm{pO}_{2}$ value was read at a fixed time of $30 \mathrm{~s}$, because we found that the green light did not indicate adequately. 

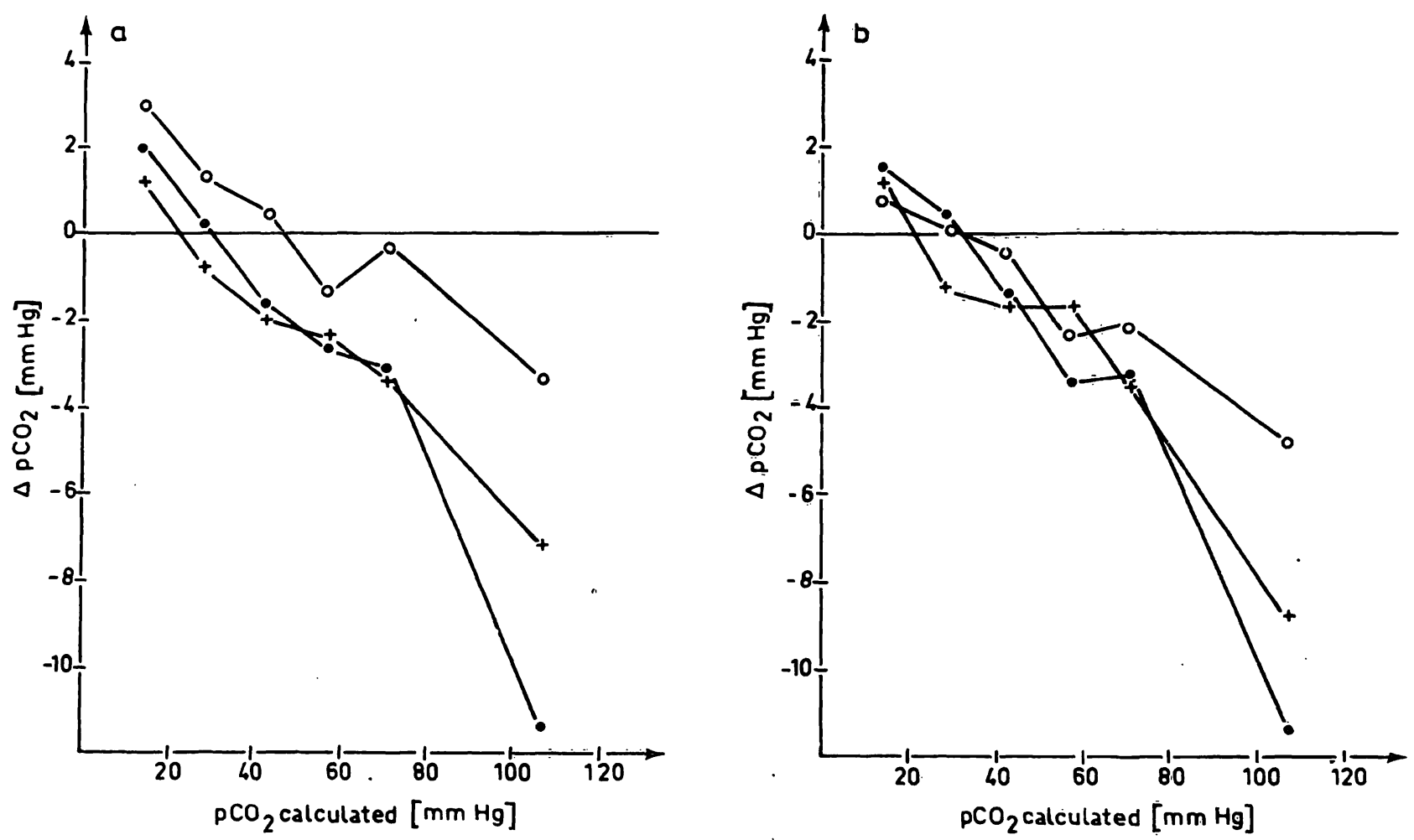

Fig. 6. Results of $\mathrm{pCO}_{2}$ measurement for blood (a) and buffer AIII (b). The difference between measured and calculated $\mathrm{pCO}$ is plotted on the $y$-axis. For blood each symbol is the mean of $\mathbf{3 0}$ measurement, and for buffer AIII it is the mean of 5 measurements.

$\bullet=\mathrm{IL}-413+=$ ABL-1 $\quad 0=$ AVL-937C

\section{Accuracy}

Table 3 presents the parameters for the linear regression analysis between calculated and measured $\mathrm{pO}_{2}$ values for the range up to $130 \mathrm{~mm} \mathrm{Hg}$. In this range for blood and buffer a linear relationship exists with a correlation coefficient better than 0.99 ; for buffer solution a large positive y-intercept was found.

Figure 8 illustrates the accuracy of the $\mathrm{pO}_{2}$ measurements at nine different levels for blood and buffer samples. Up to $130 \mathrm{~mm} \mathrm{Hg}$ the behaviour of blood and buffer is completely different: for blood, measured values hardly differ from the calculated $\mathrm{pO}_{2}$ values, whereas for buffer the difference depends on the $\mathrm{pO}_{2}$ level. At levels above $130 \mathrm{~mm} \mathrm{Hg}$, both blood and buffer showed an increase of negative difference with increasing $\mathrm{pO}_{2}$ level. This different behaviour can be explained by the presence of the residual calibration gas (about $140 \mathrm{~mm} \mathrm{Hg}$ ) in the measuring chamber. For buffer samples tonometered with lower or higher $\mathrm{pO}_{2}$ than the $\mathrm{pO}_{2}$ of the last calibration gas, measurements will be higher or lower, respectively, than the calculated values, due to contamination with the residual gas. For blood this effect is small at low $\mathrm{pO}_{2}$ values ( $<100 \mathrm{~mm} \mathrm{Hg}$ ), as hemoglobin will act as a "buffer" to moderate changes in $\mathrm{pO}_{2}$. At $\mathrm{pO}_{2}$ levels above $100 \mathrm{~mm} \mathrm{Hg}$ hemoglobin is fully saturated, so $\mathrm{pO}_{2}$.changes will primarily affect physically dissolved, rather than chemically bound oxygen; i.e. blood samples behave like buffer samples. Figure 9 shows the marked influence of the calibration gas on the measured $\mathrm{pO}_{2}$ of buffer and, to a lesser extent of blood samples for the IL blood gas analyser. Gas-fluid differences, not optimal polarizing conditions for the electrode, and residual gas in the measuring chamber can be held reponsible for the discrepancies between the measured and calculated values. It can be seen that blood samples with a $\mathrm{pO}_{2}$ in the physiological range can be measured more accurately with a calibration gas of a $\mathrm{pO}_{2}$ of $140 \mathrm{~mm} \mathrm{Hg}$ instead of the $\mathrm{pO}_{2}$ of $70 \mathrm{~mm} \mathrm{Hg}$ recommended by the manufacturer.

Generally speaking, standardization of the calibration with a fixed $\mathrm{pO}_{2}$ of about $140 \mathrm{~mm} \mathrm{Hg}$ might be an improvement. Flushing of the measuring chamber $(2-3$ times) with sample, which is only possible for IL in the manual mode, is a way oa diminishing the residual gas effect.

\section{Precision}

Table 2 shows the average precision $(\ddot{\overline{\mathrm{CV}}})$ of the $\mathrm{pO}_{2}$, which is better than $2 \%$ for blood and $3 \%$ for buffer samples.

\section{Operating notes}

During the evaluation period, the instrumentation was well maintained by checking all electrode systems and renewing membranes each two weeks. 

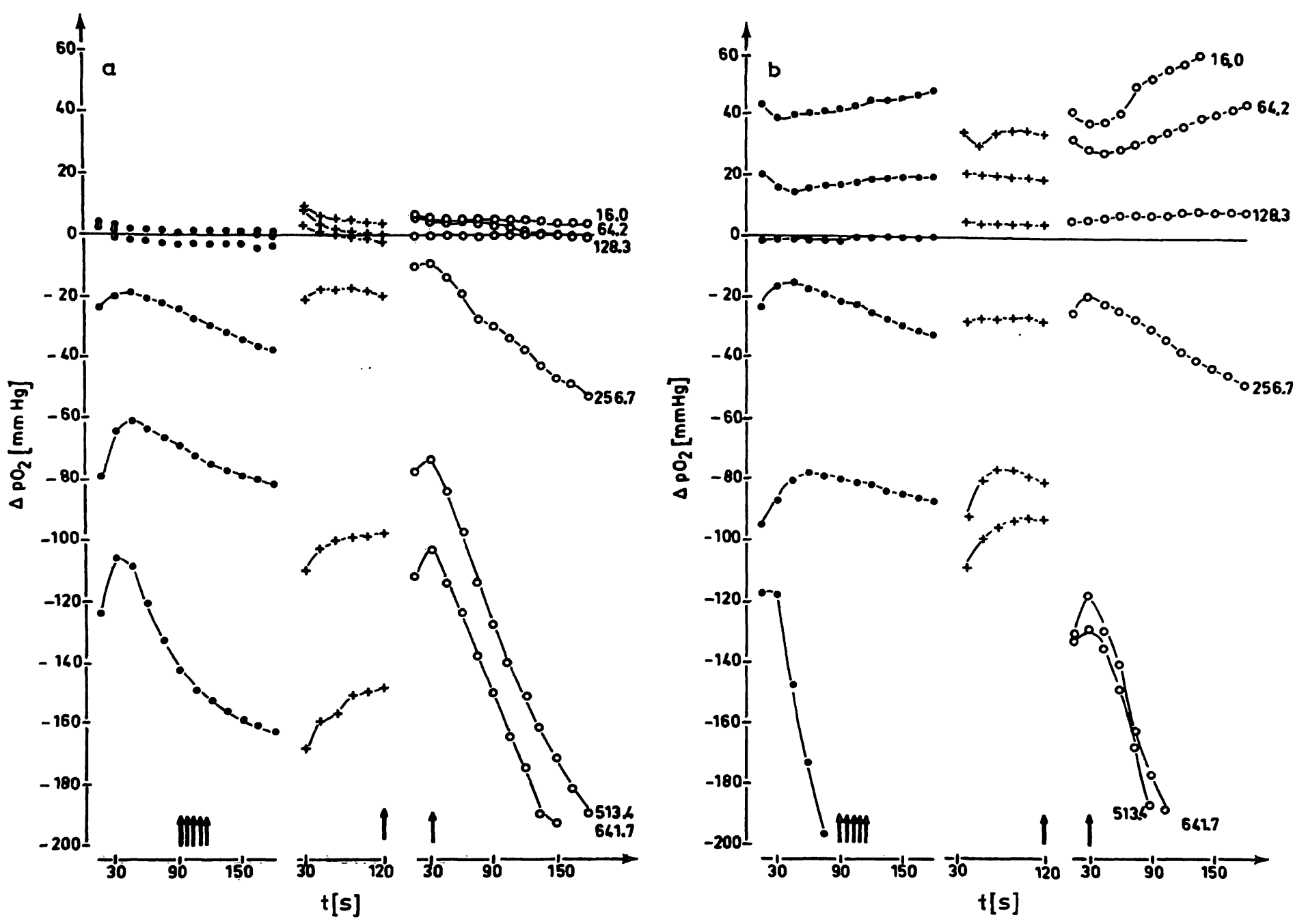

Fig. 7. $\mathrm{pO}_{2}$ response curves for blood (a) and buffer $\mathrm{AIII}(\mathrm{b})$. The difference between measured and calculated $\mathrm{pO}_{2}$ is plotted on the $y$-axis. Each symbol is the mean of a duplicate. The figures on the right side of the curves correspond to the calculated tonometer $\mathrm{pO}_{2}$ values. Arrows indicate at which time $\mathrm{pO}_{2}$ values of tonometered samples were read.

$\bullet=\mathrm{IL}-413+=$ ABL-1 $0=$ AVL-937C
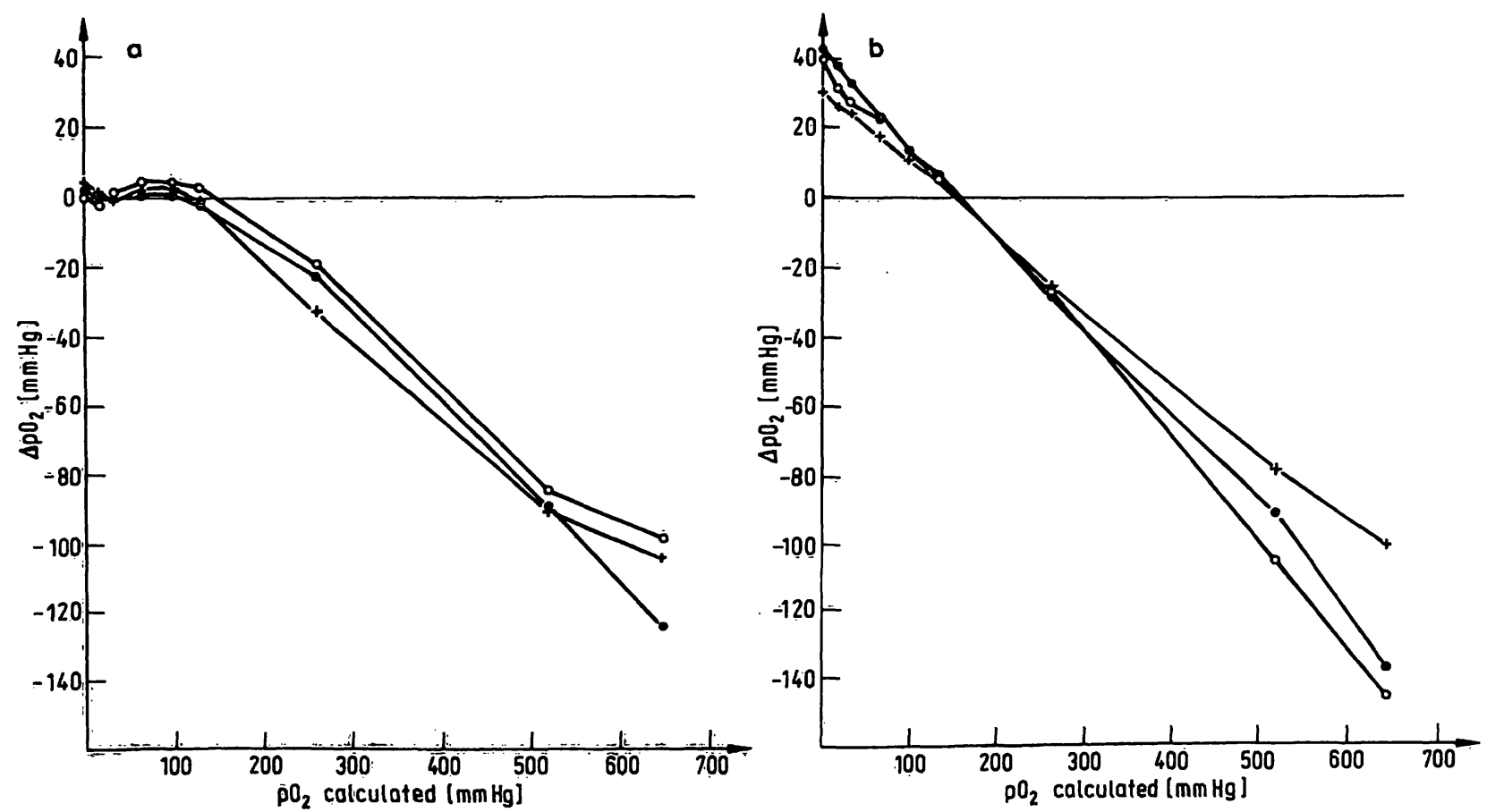

Fig. 8. Results of $\mathrm{pO}_{2}$ measurement for blood (a) and buffer $\mathrm{AIII}$ (b). The difference between measured and calculated pO $\mathrm{O}_{2}$ is plotted on the $y$-axis. For blood each symbol is the mean of 30 measurements, and for buffer AIII it is the mean of 5 measurements.

$\bullet=\mathrm{IL}-413+\doteq \mathrm{ABL}-1 \quad 0=\mathrm{AVL}-937 \mathrm{C}$ 


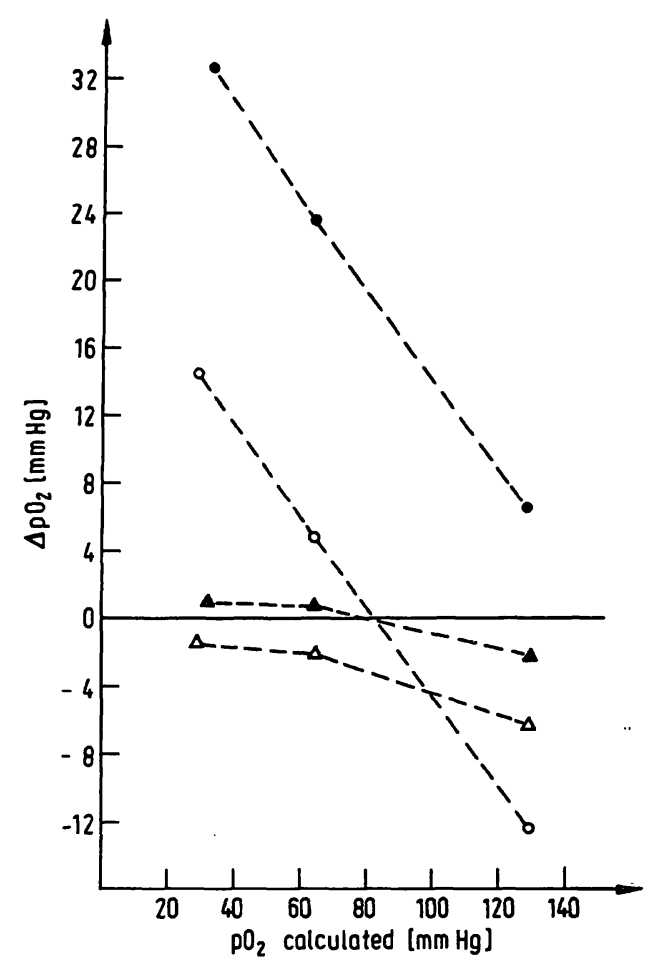

Fig. 9. The influence of the calibration gas on the results of $\mathrm{pO}_{2}$ measurement with IL for blood and buffer AIII. The difference between measured and calculated $\mathrm{pO}_{2}$ is plotted on the $y$-axis. Triangles $(\Delta, \Delta)$ correspond to blood and dots $(\bullet, \circ)$ to buffer AIII. Open symbols indicate results obtained after calibration of the electrode with $10 \% \mathrm{O}_{2}$ and closed symbols results obtained after calibration with $20 \% \mathrm{O}_{2}$.

\section{Comments on individual instruments}

IL-413

We had the opportunity to obtain experience with two IL instruments and a third one in routine use and found that the IL is easy to operate. A good filling of the system with sample can easily be controlled by visual inspection because the sample pathway and electrodes are mounted in a transparant thermostated waterbath. Most parts of the measuring circuit are readily accessible, which is an advantage especially for cleaning the easily clogged valves.

A serious problem might be gas bubbles left in the $\mathrm{pCO}_{2}-\mathrm{pO}_{2}$ measuring chamber after sampling proteinfree tonometered buffer solutions, thus causing erroneous results. We solved this problem in one instrument by boring the top of the chamber to a cone shape.

From standby position a complete calibration or a simple calibration (cal 1) with a sample measurement in duplicate can be performed in about $4 \mathrm{~min}$. Although according to the manual, a $100 \mu \mathrm{l}$ sample is sufficient in the "micro" mode, we found that about three capillary samples (total $250 \mu \mathrm{l}$ ) are needed to obtain reliable $\mathrm{pH}$ and blood gas results. It might be possible to improve operation by calibrating the glass electrode for electrical zero with buffer " 7.384 " and establishing the slope with buffer " 6.840 ".

\section{$A B L-1$}

This instrument is simple to operate, in consequence of its automation and computerisation, and it has proved trustworthy during one year of observation. The operator can hardly influence the results. The inside of the electrode chamber cannot be inspected visually and is accessible with difficulty, which is inconvenient when changing the membranes of the gas electrodes.

A complete calibration is done automatically every two hours. This does not imply that false calibrations are excluded. Dust in the gas mixing apparatus may alter the composition of the calibration gases, which results in different $\mathrm{pCO}_{2}$ and $\mathrm{pH}$ values for the equilibrated buffer solutions. The calculator does not correct for this and apparent values are printed out. Once we found a difference of 0.06 of a $\mathrm{pH}$ unit which could be easily detected using daily tonometered buffer solution for quality control $(18,19)$. In this case the gas mixing apparatus had to be replaced. The electrical checking of the electrodes through switching off the main power, which leads to temperature drop, and cleaning the computer memory, might be better performed with a separate switch instead of the main power switch.

\section{AVL-937C}

We have had two apparatus at our disposal. As already mentioned the adjustment of indication lights of both instruments was not sufficient Also the instability of the readings on the digital screen caused by static electricity was inconvenient. Simultaneous calibration of $\mathrm{pH}$ and gas electrodes is not possible which is a disadvantage in comparison with IL and ABL. With our modifications for calibration and measurement the time needed to perform a complete calibration is about $30 \mathrm{~min}$. Once this calibration had been done, the electrodes were found to be very stable with respect to calibration buffers and gases during the day. So between measurements a single calibration for $\mathrm{pH} \mathrm{pCO}_{2}$ and $\mathrm{pO}_{2}$ is sufficient and takes about $10 \mathrm{~min}$, when done in duplicate.

In "standby" position gas 1 is flowing through the capillary measuring chamber in which the electrode tips are located. Although this results in a very stable signal for the $\mathrm{pCO}_{2}$ electrode (7) and $\mathrm{pO}_{2}$ electrode, it will interfere with $\mathrm{pH}$ measurement. The time needed to stabilize the $\mathrm{pH}$ electrode after a gas flow during the night is about $15 \mathrm{~min}$. We found the same phenomenon for the gas electrodes if buffer is left in the measuring chamber overnight. The fact that the measuring chamber is rinsed with distilled water between measurements will easily give rise to a contaminating film of protein and might be better performed with saline.

An advantage of the AVL is its suitability for micro samples. 


\section{Concluding remarks}

The evaluated new generation of $\mathrm{pH}$-blood gas analysers: IL-413, ABL-1 and AVL-937C represent a great advance, in that $\mathrm{pH}, \mathrm{pCO}_{2}$ and $\mathrm{pO}_{2}$ may be measured simultaneously and automatically in one sample of blood. The analytical variables: response time, accuracy and precision of their electrode systems are comparable, with the exception of the $\mathrm{pH}$ response and $\mathrm{pH}$ difference of AVL. The IL is the fastest apparatus, the ABL is easiest in operation and the AVL most adapted to micro samples. In the (patho)physiological range all instruments may provide suitable results to the clinician.

However, when more accurate values are needed in acid base balance and oxygen transport evaluation, we feel that this instrumentation has to be standardized and improved. To achieve this we suggest the following electrode alterations:

$\mathrm{pH}$ The electrode glass should have a standard composition to avoid systematic errors. The importance of using a saturated $\mathrm{KCl}$ bridge, free of contamination should be emphasized, because a lower salt concentration lowers the results (11).

$\mathrm{pCO}_{2}$ To minimize gas exchange with the electrode electrolyte and consequently the "memory" effect, the space between the glass electrode and the holder should be very small (22). It seems also justified to apply correction factors since the deviations of different electrodes are the same as shown in this study.

\section{References}

1. Severinghaus, J. W. (1968), Ann. N. Y. Acad. Sci. 148, 115-132.

2. Severinghaus, J. W. \& Bradley, A. F. (1971), Blood Gas Electrodes or what the Instructions Didn't Say, Radiometer, Copenhagen, p. 1-47.

3. Maas, A. H. J. (1970), Clin. Chim. Acta 28, 373-390.

4. Gambino, S. R. (1965), in Standard Methods in Clinical Chemistry (Meites, S., ed.), Vol. 5, pp. 169-198, Academic Press, New York.

5. Dowd, J. \& Jenkins, L. C. (1973), Can. Anaesth. Soc. J. 20, $129-140$.

6. Berkenbosch, A. (1970), Pflügers Arch. 318, 217-224.

7. Crampton Smith, A. \& Hahn, C. E. W. (19.75), Br. J. Anaesth. $47,553-558$.

8. Hahn, C. E. W. \& Crampton Smith, A. (1975), Br. J. Anaesth. $47,559-569$.

9. Adams, A. P., Morgan-Hughes, J. O. \& Sykes, M. K. (1968), Anaesthesia 22, 575-597.

10. Adams, A. P., Morgan-Hughes, J. O. \& Sykes, M. K. (1968), Anaesthesia 23, 47-64.

11. Siggaard=Andersen, O. (1974), in The Acid=Bäse Status of the Blood pp. 145-191, Munksgaard, Copenhagen.

12. Miller, J. N. \& Tutt, P. (1967), BioMed. Eng., 456-460.

13. Hill, D. W. \& Tilsley, C. (1973), Br. J. Anaesth. 45, 647654.
$\mathrm{pO}_{2}$ Unfortunately the response of this electrode is not linear with the oxygen concentration in fluids. It seems that the optimal conditions of polarography, well studied in the beginning of the history of macro electrodes (23), are not generally known for micro electrodes. Recently Hahn et al (24) showed in a careful study, examining the electrode reaction in some detail, that non-linearity of micro $\mathrm{pO}_{2}$ electrodes is due to the absence of a plateau on the polarogram, when used with conventional electrolytes.

The use of electrolyte of $\mathrm{pH} 11.2$ and a voltage of about $-1.0 \mathrm{~V}$ results in a long, flat plateau and a marked improvement in both electrode linearity and response time; the use of this procedure is advisable.

Further, calibration of the electrodes should be uniform. Buffer solutions equilibrated with gas mixtures, as used in the $\mathrm{ABL}$, seem most suitable. Last but not least, a good quality control program should be developed to interpret optimally the $\mathrm{pH}$ and blood gas values, obtained.

\section{Acknowledgement}

The authors are indebted to the manufacturers Wilten \& Co., Etten-Leur and Laméris Utrecht, (The Netherlands) for kindly supplying the IL-413 and AVL-937 C respectively.

We thank Mrs. E. M. Stellaard-Tijmensen and Ms. I. Jansen for assistance in preparation of the manuscript.

14. Weisbrot, I. M., Kambli, V. B. \& Gorton, L. (1974), Am. J. Clin. Pathol. 61, 923-935.

15. Schurz, A. R. \& Reich, Th. (1973), Klin. Wochenschr. S1, 685-686.

16. Voigt, E. (1973), Z. Prakt. Anästh. 8, 317-319.

17. Delaney, C. J., Leary, E. T., Ralsys, V. A. \& Kenny, H. A. (1976), Clin. Chem. 22, 1675-1684.

18. Veefkind, A. H., Van den Camp, R. A. M. \& Maas, A. H. J. (1975), Clin. Chem. 21, 685-693.

19. Maas, A. H. J., Veefkind, A. H., Van Den Camp, R. A. M. Teunissen, A. J., Winckers, E. K. A. \& Jansen, A. P. (1977), Clin. Chem. 23,1718-1725.

20. Scott-Emukapor, D., Maas, A. H. J., Ruigrok, T. J. C. \& Zimmerman, A. N. E. (1976), Pflügers Arch. 363, 141-147.

21. Maas, A. H. J. \& van Hèijst, A. N. P. (1965), Pflügers Arch. 284, 191-194.

22. Arndt, H., Brink, H., Lübbers, D. W. \& Maas, A. H. J. (1966), Pflügers Arch. 288, 282-296.

23. Gleichman, U. \& Lübbers, D. W. (1960), Pflügers Arch. 271 , 431-455.

24. Ḧahn, C. E. W., Davis, A. H. \& Albery, W. J. (1975), Respir. Phyśiol. 25, 109-133.

Dr. A. H. J. Maas

Department of Cardiology

University Hospital, Catharijnesingel 101

Utrecht, The Netherlands 


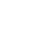

